Sebastian Wiśniewski ${ }^{1}$

Uniwersytet im. Adama Mickiewicza w Poznaniu

\title{
Głoszenie Ewangelii podczas wypraw rowerowych na przykładzie działalności Niniwa Team
}

Wezwanie Kościoła do wyjścia na peryferie, sformułowane przez papieża Franciszka w adhortacji Evangelii gaudium doczekało się już wielu interpretacji i propozycji ukonkretnienia ${ }^{2}$. Skoro we wszystkich miejscach na ziemi Kościół ma być $w$,permanentnym stanie misji” (EG 25), oznacza to, że przesuwają się albo nawet zanikają także granice pomiędzy wierzącymi i niewierzącymi. Jak zauważył kard. Ratzinger, „nikt nie może uniknąć całkowicie wątpienia ani całkowicie wiary; dla jednych wiara będzie istniała przeciw wątpieniu, dla drugich przez wątpienie i w formie wątpienia"3. Nie ma już zatem miejsc typowo misyjnych, ponieważ wszędzie jest miejsce na typowe misje. Ponadto Kościół przypomina

1 Sebastian Wiśniewski OMI - doktor nauk teologicznych, logopeda, autor i redaktor publikacji książkowych, artykułów naukowych i kazań, wykładowca w Wyższym Seminarium Duchownym Misjonarzy Oblatów Maryi Niepokalanej w Obrze na Wydziale Teologicznym Uniwersytetu im. Adama Mickiewicza w Poznaniu. Obszar badań: kaznodziejstwo, problem wiary głoszonej i przeżywanej, wiara i nawrócenie, doskonałość chrześcijańska, skuteczność głoszonego orędzia. E-mail: sebastian.wisniewski@oblaci.net.

2 Zob. Franciszek, adhort. apost. Evangelii gaudium [dalej: EG], 20.

3 J. Ratzinger, Wprowadzenie w chrześcijaństwo, tłum. Z. Włodkowa, Kraków 2006, s. 43. 
o powszechnej odpowiedzialności chrześcijan za misję ewangelizacyjną i o obowiązku misyjnym ${ }^{4}$. Każdy chrześcijanin na mocy chrztu jest wezwany do głoszenia Ewangelii - zarówno świadectwem swojego życia, jak i słowem głoszonym - najpierw sobie, później tym, którzy są najbliżej, w końcu każdemu, kto czeka na światło Ewangelii.

Jedną z dość szczególnych form ewangelizacyjnego wychodzenia na peryferie jest działalność wspólnoty Niniwa Team, podejmującej długodystansowe wyprawy rowerowe (najdłuższa liczyła $8500 \mathrm{~km})^{5}$, które cieszą się wielkim zainteresowaniem młodzieży ${ }^{6}$ oraz środków społecznego przekazu, przez co rozgłos zyskują nie tylko uczestnicy rowerowych pielgrzymek, ale także Chrystus, na którego się powołują. Pozostaje jednak pytanie, czy wyprawy turystyczne są rzeczywiście dobrze wykorzystaną okazją do głoszenia Ewangelii? W celu odnalezienia odpowiedzi na to pytanie zostaną przebadane relacje $\mathrm{z}$ wypraw rowerowych organizowanych przez Niniwa Team. Do roku 2017 odbyło się już 11 kilkutygodniowych wypraw, w których za każdym razem uczestniczy średnio około 30 rowerzystów ${ }^{7}$. W celach badawczych zostanie zastosowana metoda analityczna, która pozwoli uporządkować wypowiedzi w kluczu poszukiwanej odpowiedzi, oraz metoda syntetyczna, dzięki której będzie możliwe sformułowanie oczekiwanych wniosków.

\section{Głoszenie Ewangelii ad intra}

Jak zauważył papież Paweł VI w adhortacji Evangelii nuntiandi, 15, „Kościół jako głosiciel Ewangelii zaczyna swe dzieło od ewangelizowania samego siebie. Jako wspólnota wierzących, jako wspólnota nadziei

4 Wystarczy przywołać chociażby adhortację Pawła VI Evangelii nuntiandi [dalej: EN], encyklikę Jana Pawła II, Redemptoris missio [dalej: Rmis] czy też adhortację Franciszka Evangelii gaudium.

5 Zob. Polska - Syberia. Dokąd?, http://niniwa.org/niniwa-team/dokad-2-2/ (20.09.2017).

6 W wyprawach rowerowych bierze udział po kilkadziesiąt osób (zob. http://niniwa. org/niniwa-team/ekipa/).

7 Zob. http://niniwa.org/niniwa-team/niniwa-team/ (20.09.2017). 
wyrażanej życiem i dzielonej z innymi oraz wspólnota braterskiej miłości, musi ciągle słuchać tego, w co wierzy, i motywów swej nadziei, i nowego przykazania miłości”. Oznacza to konieczność pamiętania, że pierwszym adresatem aktywności ewangelizacyjnej Kościoła jest on sam. Już św. Paweł wzywał Kolosan, by pozwolili słowu Chrystusa trwać w ich sercach i by napominali samych siebie przez hymny, psalmy i pieśni pełne ducha (zob. Kol 3, 16). W relacjach z wypraw rowerowych organizowanych przez Niniwa Team bardzo mocno i wyraźnie wybrzmiewa ten właśnie autoewangelizacyjny aspekt działalności grupy ${ }^{8}$.

Ważnym sposobem samoewangelizacji jest głoszenie wewnątrz grupy i przyjmowanie przez jej członków słowa Bożego. Jakkolwiek jest to proces trudny i wymagający odważnej konfrontacji własnych ograniczeń z wymaganiami słowa Bożego, to jednak uczestnicy wypraw stwierdzają z satysfakcją: „układaliśmy codzienność według Ewangelii, według Słowa, przez które mówił Bóg. [...] Nikogo nie męczyła codzienna msza święta. W sytuacji wyprawy to naprawdę uczta miłości, to karmienie się Bogiem, który jest Miłością. [...] To odkrycie przez młodych jest największym sukcesem tej wyprawy. Do tego odkrycia dążyliśmy". Otwieranie się na głoszone słowo Boże było weryfikowane przez trudności samej drogi, która okazywała się często nieprzewidywalna i mało bezpieczna, przez co uczyła pątników pokory i wiary ${ }^{10}$. Świadectwo wiary właśnie jest nicią łączącą wszystkie wyprawy ${ }^{11}$. Wiara, która budzi się jako owoc słuchania słowa Bożego, weryfikuje się w postawie nawrócenia, ponieważ jest „martwa bez uczynków” (Jk 2, 26). Chcąc poznawać wolę Bożą i potwierdzać swoją wiarę uczynkami, trzeba koniecznie otwierać się

8 Lider wypraw, T. Maniura, we Wstępie do książki Wyprawa 2013. Polska-Syberia, red. K. Zieliński, T. Maniura, Lubliniec-Kokotek 2016, s. 7, stwierdził: „To prawdziwe, twarde, realne rekolekcje. Niejednokrotnie brutalne stawanie oko w oko z prawdą o sobie. To bardzo praktyczne uczenie się Boga, który jest Miłością. To wielka sztuka akceptowania drugiego człowieka takiego, jakim jest i przyjmowania go [...]. W końcu to odkrywanie Bożej obecności we wszystkim".

9 T. Maniura, Wstęp, w: Wyprawa 2013..., dz. cyt., s. 8.

10 Por. T. Maniura, Wstęp, w: Misja JuT. Ostatnie okrążenie, albo i nie..., red. K. Zieliński, T. Maniura, Lubliniec-Kokotek 2016, s. 10.

11 Por. T. Maniura, Wstęp, w: K. Zieliński, T. Maniura, Misja BXVI. Nordkapp, LubliniecKokotek 2012, s. 8. 
na słowo Boże. Uczestnicy wypraw dawali wyraz przekonaniu, że słowo Boże należy przeżuwać, co więcej, nawet „właśnie po to jedzie się dziesięć godzin dziennie na rowerze, żeby słowo się przetrawiło. Żeby można je przyjąć do siebie, po tym jak rano się je usłyszy"12. Wydaje się, że nie jest to tylko przekonanie czy też założenie organizatorów wypraw. Oto jedna z wypowiedzi uczestników: „Cała nasza grupa miała świadomość, że każdy przejechany kilometr przybliża nas do celu. Jednak to nie Nordkapp był najważniejszy. Głównym celem okazało się zbliżenie do Pana Boga. Opatrzność i słowo Boże prowadziły nas na każdym kroku. Przeżywaliśmy to duchowo, ale dla nas było to również widocznie, wręcz namacalnie” ${ }^{13}$. Inna uczestniczka stwierdza: „Gdybym miała podsumować całą wyprawę jednym zdaniem, niewątpliwie byłoby to: «Cuda! Cuda wszędzie». Podczas całego miesiąca nie było chyba dnia, żeby nie wydarzył się jakiś cud. Często miał on również jakieś odniesienie do słowa Bożego na dany dzień (które, notabene, każdego dnia na swój sposób się spełniało)"14. Uczestnicy rzeczywiście mieli możliwość codziennego słuchania słowa Bożego chociażby podczas sprawowanych Eucharystii. Najważniejsze jednak, że dawali się także ewangelizować przez słowo zwiastowane podczas mszy świętych. Duszpasterz pielgrzymów nie zawahał się nawet wejść po pas do Jeziora Galilejskiego, żeby z tej perspektywy głosić Dobrą Nowinę i jeszcze skuteczniej zapisać słowo Boże w pamięci i sercach słuchaczy ${ }^{15}$.

W refleksji po jednej z wypraw lider grupy zauważył, że „droga [...] kształtuje umiejętność przyjmowania życia takim, jakie ono jest, człowieka takiego, jakim jest. Człowiek, który jest w drodze, rozumie, że niewiele od niego zależy. Można się bardzo starać, wszystko zaplanować, włożyć dużo pracy i wysiłku, a najczęściej jest inaczej”" Wyprawy stwarzały także okazje do tego, by pokonywać ograniczenia własnego egoizmu i otwie-

12 K. Zieliński, T. Maniura, Misja BXVI. Nordkapp, Lubliniec-Kokotek 2012, s. 131.

13 S. Brajlich, Wspomnienia uczestników, w: K. Zieliński, T. Maniura, Misja BXVI. Nordkapp, dz. cyt., s. 295.

${ }_{14}$ J. Kotas, Wspomnienia uczestników, w: K. Zieliński, T. Maniura, Misja BXVI. Nordkapp, dz. cyt., s. 300 .

15 Zob.: 3,6 s-Ekspedycja Jerozolima, red. K. Zieliński, Lubliniec-Kokotek 2011, s. 135.

16 T. Maniura, Wstęp, w: Misja JuT..., dz. cyt., s. 10. 
rać się na innych uczestników ${ }^{17}$. Szczególnie w chwilach kryzysowych, kiedy np. ktoś z ekipy potrzebował pomocy, uwidaczniała się chrześcijańska postawa pozostałych - Ewangelia była zatem zwiastowana życiem w nieprzewidzianych sytuacjach. Jeden z uczestników wspomina: „W drugim tygodniu całe zmęczenie jakby ze mnie zeszło i jechało mi się bardzo dobrze. Aż po około $100 \mathrm{~km}$ - upadek, złamane koło, rozcięty łuk brwiowy, uszkodzone okulary... Wtedy zobaczyłem, z jakimi wspaniałymi ludźmi jadę, jak bezinteresownie i z zaangażowaniem udzielają pomocy. Zanim się zorientowałem, już byłem opatrzony [...], a rower został złożony przez grupę techniczną"18. Nieprzewidywalne okoliczności pozwalały zatem uczestnikom odkrywać w sobie rysy miłosiernego Samarytanina i w ten sposób stawały się impulsem do spontanicznego ewangelizowania towarzyszy drogi. Tego rodzaju doświadczenia są bardzo ważne w tworzeniu więzi i wzajemnym ewangelizowaniu wewnątrzwspólnotowym, ponieważ człowiek nie może tylko i wyłącznie dawać miłości, ale musi jej także doświadczać, jak wyraził się papież Benedykt XVI: „Kto chce dawać miłość, sam musi ją otrzymać w darze" ${ }^{19}$.

Uczestnicy wypraw wiele razy mogli doświadczyć tego, że pomiędzy miłością i wiarą zachodzi relacja wzajemnych zależności. Z jednej strony bowiem „wiara [...] działa przez miłość” (Ga 5,6), z drugiej zaś „miłość bez wiary byłaby uczuciem nieustannie na łasce i niełasce wątpliwości. Wiara i miłość potrzebują siebie nawzajem, tak że jedna pozwala drugiej się realizować”20. W relacjach uczestników widać wyraźnie wiarę realizowaną, przeżywaną, a nie tylko deklarowaną. Organizator wyprawy, o. Tomasz Maniura OMI, wspomina: „Był taki tydzień, na samej północy Europy. Brakło cywilizacji. Naprawdę nie wiedziałem nic, do tego mając świadomość odpowiedzialności za całą ekipę. Nie wiedziałem, czy nazbieramy chrustu, żeby rozpalić ognisko, czy nie przyjdzie jakiś większy mróz, czy ktoś się nie rozchoruje, czy będzie woda, jedzenie. Ta wyprawa rzucała na kolana i z każdym przejechanym kilometrem dawała pewność

17 Zob. R. Jaruszowiec, Wspomnienia uczestników, w: Misja JuT..., dz. cyt., s. 376; A. Kępiński, Wspomnienia uczestników, w: Misja JuT..., dz. cyt., s. 377.

18 S. Zieliński, Wspomnienia uczestników, w: Misja JuT..., dz. cyt., s. 395.

19 Benedykt XVI, enc. Deus Caritas est, 7.

20 Benedykt XVI, list Porta Fidei, 14. 
wiary. Tam modlitwa naprawdę stawała się oddechem. Wszystko stało się modlitwą. To było Boże doświadczenie" ${ }^{21}$. W tym kontekście zrozumiałe stają się słowa lidera wypraw o tym, że „wiara karmi się życiem, tylko trzeba spojrzeć na to życie z wiarą" 22 .

Jednym z najważniejszych postulatów ewangelizacyjnych jest wprowadzanie człowieka w doświadczenie Boga, ponieważ - jak wyraził się papież Franciszek w Lumen Fidei - wiara rodzi się nie tylko ze słuchania, ale także ze spotkania (zob. LF 51). Oznacza to konieczność odkrywania obecności Boga, w którym „żyjemy, poruszamy się i jesteśmy” (Dz 17, 28). Okazuje się, że podróże rowerowe są dobrą okazją do doświadczania bliskiej obecności Boga ${ }^{23}$. To doświadczenie ma być jednak pielęgnowane także po osiągnięciu celu wędrówki. Wyprawa jako wydarzenie wiary ma znaleźć swoją kontynuację w prozie życia. Wymownym wyrazem tego przekonania stało się ukończenie wędrówki na Nordkapp jakby bez osiągnięcia pełni kilometrów ${ }^{24}$.

Ewangelizacja prowadzi nie tylko do subiektywnego przeżycia wiary, ale także do odkrycia wspólnoty w różnych jej wymiarach. Pierwszym jest wymiar wspólnoty uczniów zgromadzonych wokół Jezusa Chrystusa Najwyższego Kapłana. Wyprawy dawały uczestnikom impuls do pogłębienia świadomości eklezjalnej w najbardziej prostych sytuacjach, jak np. brak możliwości sprawowania niedzielnej Eucharystii w znanych dotąd wszystkim pielgrzymom warunkach: „Dziś niedziela. Dla katolika skojarzenie z Mszą świętą jest (a przynajmniej powinno być) jasne. [...] Na wyprawie rowerowej Eucharystia nie musi się odbyć w budynku. Ważne

${ }^{21}$ T. Maniura, Wspomnienia uczestników, w: K. Zieliński, T. Maniura, Misja BXVI. Nordkapp, dz. cyt., s. 294.

22 T. Maniura, Wstęp, w: K. Zieliński, T. Maniura, Misja BXVI. Nordkapp, dz. cyt., s. 8.

${ }_{23}$ Zob. T. Maniura, Wstęp, w: K. Zieliński, T. Maniura, Misja BXVI. Nordkapp, dz. cyt., s. 9. T. Maniura, Wstęp, w: Misja JuT..., dz. cyt., s. 7, wyjaśnia: „To my podczas tych ośmiu tygodni jazdy intensywniej niż na co dzień w swoich domach uczyliśmy się przyjmować Bożą miłość we wszystkim".

${ }_{24}$ T. Maniura, Wstęp, w: K. Zieliński, T. Maniura, Misja BXVI. Nordkapp, dz. cyt., s. 9, stwierdził: „Z założenia mieliśmy przejechać $4000 \mathrm{~km}$ w intencji papieża. Zakończyliśmy na symbolicznych 3999 km, żeby nie przestać jechać z wiarą, żeby do końca życia słuchać Jego głosu i dać się Jemu prowadzić. By dalej oddychać świeżym powietrzem, Bogiem i czerpać, jak na wyprawie, ze wszystkiego, co na tym świecie się znajduje, bo to wszystko dla nas". 
jest przeżywanie jej we wspólnocie. Dziś został uczyniony kolejny krok do zbudowania tej wspólnoty"25. Drugim wymiarem przeżywania misterium wspólnoty uczniów Jezusa jest silnie odczuwana więź z Kościołem ${ }^{26}$. Rowerzyści pozwalali, żeby np. na Litwie ewangelizowało ich samo błogosławieństwo jednego z emerytowanych biskupów: „Podczas Mszy obecny był również miejscowy biskup emeryt (86 lat), który posługiwał w konfesjonale, a na końcu pobłogosławił rowerzystów. [...] Sprawa jest budująca, bo grupa doświadcza silnej łączności z Kościołem, w intencji którego jedzie. Biskupi to przecież «koledzy» papieża!"”7. Podczas tej samej wyprawy doszło także do spotkania z ks. kardynałem Jānisem Pujatsem, który „powiedział [...] sporo dobrych słów o szczytnej intencji rajdu i stwierdził dobitnie: «Ja się będę modlił, ale wy też macie się modlić!» i pobłogosławił rowerzystów. To dla nas wyraźny znak, że Pan Bóg chce tej wyprawy i błogosławi pielgrzymom przez ręce biskupów. Z pewnością nadejdą jeszcze trudniejsze chwile na wyprawie i wtedy warto, żeby uczestnicy mieli świadomość, że to Kościół ich posyła i jest razem z nimi"28.

Wyprawy - jak dobre rekolekcje - często dawały uczestnikom wzrost $\mathrm{w}$ osobistej odpowiedzi na Boże zaproszenie do wiary. Jedna z uczestniczek stwierdza wprost: „Z [...] wyprawy wróciłam umocniona w wierze. Przekonałam się o słuszności drogi, którą kroczę, i nabrałam odwagi do wyznawania mojej wiary. Nauczyłam się wytrwałości i podejmowania trudu, a czasem nawet cierpienia"29. Ewangelizowały nie tylko sakramenty, przeżywanie wspólnoty czy sama droga z jej trudnościami, ale także rozmowy z innymi towarzyszami drogi. Zaskakująco w tym kontekście brzmi świadectwo jednego z uczestników: „Dziś Agata uczyła mnie przebaczenia i modlitwy za nieprzyjaciół. To nie jest łatwe, wręcz przeciw-

25 K. Zieliński, T. Maniura, Misja BXVI. Nordkapp, dz. cyt., s. 59.

26 T. Maniura, Wspomnienia uczestników, w: K. Zieliński, T. Maniura, Misja BXVI. Nordkapp, dz. cyt., s. 295, stwierdził z przekonaniem: „Ofiarując swój mizerny trud za papieża Benedykta XVI, czułem jedność z nim i z całym Kościołem”.

${ }_{27}$ K. Zieliński, T. Maniura, Misja BXVI. Nordkapp, dz. cyt., s. 57.

28 K. Zieliński, T. Maniura, Misja BXVI. Nordkapp, dz. cyt., s. 76.

29 K. Szendzielorz, Wspomnienia uczestników, w: Tour de Mazenod. Rowerami do Maroka, red. K. Zieliński, Lubliniec-Kokotek 2011, s. 294. 
nie - to jest krańcowo trudne. Ja mam przed sobą przebaczenie ludziom, którzy z całą premedytacją zrobili wiele złego mnie i mojej rodzinie... Trzeba się zmierzyć z tym, już od dzisiaj"30.

Ewangelizują nas nie tylko słowa i spotkania z Bogiem, ale także odkrywanie śladów Bożej dobroci w prozaicznych wydarzeniach dnia. To one bowiem najmocniej przekonują o działaniu Bożej opatrzności.Podczas jednej z wypraw na przykład do rowerzystów podszedł pewien człowiek i wręczył im 20 litów: „Pieniądze się nie zmarnowały, bo oto po obiedzie wszyscy poszli na lody, a za 15 litów kupiono śpiwór dla Sławka [...]"31. Jednym z zasadniczych rysów każdej wyprawy jest właśnie zaufanie Bożej opatrzności, czego wyrazem jest chociażby to, że uczestnicy wyruszają w drogę „bez pieniędzy na noclegi, bez rezerwowania ich, bez auta technicznego i bagażowego, w nieprzewidywalnej pogodzie, z tak wieloma uczestnikami, z założeniem średniego dystansu przynajmniej $150 \mathrm{~km}$ dziennie [...]" ${ }^{32}$. Zaufanie do Bożej opatrzności, jakkolwiek charakterystyczne dla każdej wyprawy, szczególnie wyraźne było podczas „Wyprawy w nieznane”, zorganizowanej w intencji pokoju na świecie. Już sama nazwa wyprawy „w nieznane” skłania do refleksji ${ }^{33}$. Rowerzyści wyruszyli w całkowitym zaufaniu, że skoro Pan Bóg ich zainspirował do podjęcia trudu wędrówki w konkretnej intencji, to wskaże im również właściwe ścieżki. To przekonanie - jakkolwiek zrealizowane dosłownie, można także odczytać w kluczu metaforycznym - Bóg ma prawo wyznaczyć kierunek życia człowieka.

W relacjach spisywanych przez rowerzystów można z łatwością odnaleźć fascynację pięknem stworzonego świata i hojnością Boga, który opiekuje się człowiekiem i całym stworzeniem: „Po drodze zdarzyły się co najmniej trzy konkretne cuda - znaki Bożego wsparcia! Cud I. Na niebie pojawia się piękna, pełna i kolorowa tęcza! Ten znak dla nas to nie żadne liberalne symbole wyzwolenia i tolerancji. Biblijnie to znak przymierza Boga z człowiekiem. To dla Noego Bóg położył pierwszy raz ten

30 Wyprawa w nieznane, red. P. Zakowicz, T. Maniura, Lubliniec 2014, s. 115.

31 K. Zieliński, T. Maniura, Misja BXVI. Nordkapp, dz. cyt., s. 57.

32 T. Maniura, Wstęp, w: Wyprawa 2015. Radość życia, red. K. Zieliński, T. Maniura, Lubliniec-Kokotek 2015, s. 6. Zob. także: U. Machelska, Projekt organizacji wyprawy rowerowej $z$ Polskina Syberię. Praca magisterska, [mps, praca magisterska], Politechnika Śląska [brw], s. 37.

33 Zob. Wyprawa w nieznane, dz. cyt. 
łuk na niebie. Dziś położył go dla rowerzystów. Pod łukiem zaś położył renifery skubiące zieloną trawę. [...] Cud II. Po $75 \mathrm{~km}$ (czyli dokładnie $50 \mathrm{~km}$ dalej) Pan Bóg po raz drugi kładzie swój łuk na niebiosach. Tym razem jeszcze większy! [...] Cud III. Po $125 \mathrm{~km}$ jazdy (kolejne $50 \mathrm{~km} . .$.$) Zgadnij,$ co się dzieje, Drogi Czytelniku. Yyy, tęcza? Trafiony, zatopiony! Czy takie regularne znaki coś sugerują? Na pewno podbudowały śmiałków, dając im więcej siły do jazdy" ${ }^{34}$. Jakkolwiek można by na różne sposoby analizować powyższą wypowiedź, to jednak trudno odmówić jej dziecięcego zauroczenia wszystkim, co jest wokół. Trudno także nie odnaleźć w takich wypowiedziach znamiennego echa słów Jezusa, który zachęcił uczniów: „Przypatrzcie się ptakom podniebnym [...], liliom polnym” (Mt 6, 26.28).

Umiejętność obserwowania życia i odkrywania w nim Bożego działania prowadzi samych uczestników do ewangelicznej wdzięczności za wszystko, co otrzymują od Boga. Lider NINIWA Team stwierdza: „Uczę się na wyprawach widzieć dużą wartość tego, co małe i okazuje się, że nie ma małych rzeczy. Wszystko jest wielkie, darmowe, niezasłużone. W zasadzie zawsze mam więcej, niż potrzebuję, na pewno mam wszystko, co jest mi do zbawienia potrzebne" ${ }^{35}$. Jedna z uczestniczek dopowiedziała: „Doświadczyliśmy tak wielu cudów, że osobiście czułam obecność i troskę naszego Ojca. Jednak pomimo tych doświadczeń Bożej opatrzności podczas tegorocznej wyprawy przekonałam się, jak niewielką wciąż mam wiarę [...]. Uczestniczyłam już w kilku wyprawach, na których zawsze wyraźnie czułam obecność i troskę naszego Ojca"36.

\section{Głoszenie Ewangelii ad extra}

PapieżJan Paweł II zauważył, że współczesnym areopagiem jest z pewnością świat środków społecznego przekazu, który sprawia, że człowiek zaczyna żyć w „światowej wiosce” (RMis 37). Dzięki informacjom

\footnotetext{
34 K. Zieliński, T. Maniura, Misja BXVI. Nordkapp, dz. cyt., s. 209-210.

35 T. Maniura, Wspomnienia uczestników, w: K. Zieliński, T. Maniura, Misja BXVI. Nordkapp, dz. cyt., s. 294.

${ }_{36}$ B. Fleiszner, Wspomnienia uczestników, w: K. Zieliński, T. Maniura, Misja BXVI. Nordkapp, dz. cyt., s. 299.
} 
o wyprawach rowerowych, które były przekazywane w środkach społecznego przekazu, Niniwa Team zyskała mocny walor ewangelizacyjny. O trudzie wędrowców było głośno w takich mediach, jak: „Gość Niedzielny”, „Dziennik Zachodni”, Radio eM, Radio Nadzieja, „Przewodnik Katolicki”, „Miesięcznik Katolicki LIST”, Radio Piekary, „Misyjne Drogi”, Internetowa Telewizja Lubliniecka, portale lubliniec. info, lomzynskie24.pl, naszdziennik.pl, podlasie24.pl, a także „Tygodnik Gwarek” i Radio Katowice ${ }^{37}$. Jak zaznaczył organizator wypraw: „Gazety się rozpisały, radia nadawały i telewizje pokazywały. Po co? Tania popularność, chęć rozgłosu? Chcemy pokazywać, że «to» działa. Co działa? Rowery? Nie, one często się psuły. Działa miłość. [...] Tylko Bóg potrafi kochać do końca, zawsze i każdego. [...] Na pewno tym ambitnym stylem uruchamiamy media. I o to chodzi. Trochę prowokujemy kilometrami i liczebnością grupy. Po co? Żeby pokazywać, że warto żyć wg nauczania Jezusa Chrystusa. Śmiało stwierdzam, że nie ma ewangelizacji bez prowokacji. Dobrej prowokacji. Takiej, jakiej używał Jezus. Sam dokonywał rzeczy niemożliwych. Prowokował dobrem, miłością, przebaczeniem. Staramy się iść, a raczej jechać, Jego drogą. On jest Drogą"38. Dążenie wyrażone tymi słowami jest bardzo wyraźnym ukazaniem ewangelizacyjnych odniesień wyprawy samej w sobie. Skoro jednym z najważniejszych elementów ewangelizacji jest świadectwo samego życia ludzi wierzących (zob. EN 41; RMis 42), to z pewnością trudno także odmówić walorów ewangelizacyjnych wyprawom rowerowym, które zawsze miały wyraźną motywację nadprzyrodzoną. Motywacja uczestników wypraw była również osadzona mocno na pragnieniach ewangelizacyjnych, aby wyznać wiarę w Jezusa, „Boga, który stał się człowiekiem, w Jezusa, który się trudził i męczył, który odpoczywał, który szedł za swoim Ojcem, który ufał, i w Jezusa, który przede wszystkim zawsze kochał" ${ }^{39}$. Takie rozumienie tych unikalnych i ekstremalnych zarazem pielgrzymek rowerowych zdaje się korespondować z refleksją papieża Jana Pawła II, wyra-

\footnotetext{
37 T. Maniura, Wstęp, w: K. Zieliński, T. Maniura, Misja BXVI. Nordkapp, dz. cyt., s. 10.

38 T. Maniura, Wstęp, w: Wyprawa 2013..., dz. cyt., s. 8.

39 T. Maniura, Wspomnienia uczestników, w: K. Zieliński, T. Maniura, Misja BXVI. Nordkapp, dz. cyt., s. 295.
} 
żoną w Redemptoris missio, 11, gdzie ojciec święty stwierdził, że „dzisiejszą pokusą jest sprowadzanie chrześcijaństwa do mądrości czysto ludzkiej, jakby do wiedzy o tym, jak dobrze żyć. W świecie silnie zsekularyzowanym nastąpiło «stopniowe zeświecczenie zbawienia», dlatego walczy się, owszem, o człowieka, ale o człowieka pomniejszonego, sprowadzonego jedynie do wymiaru horyzontalnego. My natomiast wiemy, że Jezus przyszedł, by przynieść zbawienie całkowite, które obejmuje całego człowieka i wszystkich ludzi, otwierając ich na wspaniałe horyzonty usynowienia Bożego".

Poza tym wyprawy mają zawsze jakąś konkretną intencję: o pokój, za papieża, za dzieci głodujące w Afryce czy też za tych, „którzy często już nawet w młodym wieku bywają uzależnieni lub zniechęceni do życia przez jakieś złe doświadczenia w domu czy w środowisku, w którym się obracają" ${ }^{40}$. Poszczególne intencje bardzo dobrze odpowiadają współczesnym areopagom, które wyliczył papieżJan Paweł II w Redemtoris missio, 37, stwierdzając, że „jest wiele [...] «areopagów» współczesnego świata, ku którym winna się kierować działalność misyjna Kościoła. Na przykład zaangażowanie na rzecz pokoju, rozwoju i wyzwolenia ludów, praw człowieka i narodów, przede wszystkim mniejszości, działanie na rzecz kobiety i dziecka, ochrona świata stworzonego, to wszystko dziedziny ludzkiej działalności, które należy rozjaśnić światłem Ewangelii”. Relacje z wypraw pozwalają zauważyć, że uczestnicy mieli żywą świadomość konieczności ewangelizowania spotykanych ludzi ${ }^{41}$.

Do niecodziennych wydarzeń związanych z Niniwa Team można z całą pewnością zaliczyć ślub dwojga uczestników, którzy zawarli sakrament małżeństwa w Wierszynie na Syberii, dokąd zawędrowali z Polski rowerami: „Tak długiej podróży przedślubnej chyba nie miał nikt na świecie. Dla Sary była to już siódma wyprawa z Niniwa Team. Dla Piotrka decyzja

40 T. Maniura, Wstęp, w: Tour de Mazenod..., dz. cyt., s. 9.

${ }^{41}$ Jeden z uczestników z przekonaniem stwierdził: „Słowo mówi nam dziś, że każdy człowiek przed Bogiem ma równie ogromną wartość i każdy z nas jest powołany do świętości, bez względu na swoją osobistą sytuację. Podczas wyprawy ekipa mijała różnych ludzi z różnych kultur, bogatych i biednych, poukładanych i z porozbijanym życiem. A przecież każdy z nich tak samo potrzebuje Jezusa, Jesteśmy powołani, by nieść ludziom wieść o Zbawicielu" (Misja JuT..., dz. cyt., s. 297). 
była znacznie trudniejsza, ale motywację dojechania do Wierszyny miał ogromną" ${ }^{2}$. Sakrament małżeństwa zawarty przez młodych uczestników wyprawy niedaleko jeziora Bajkał, 100 km od Irkucka, gdzie przez kilkadziesiąt lat z determinacją starano się wykorzenić ewangeliczny styl życia oraz sposób wartościowania i myślenia o świecie, nabiera szczególnie intensywnego kolorytu ewangelizacyjnego.

Uczestnicy głosili Ewangelię bardzo praktycznie - pokazując najpierw swoje osobiste zaufanie do Boga i wiarę w to, że czuwa nad nimi Boża opatrzność. Rzeczywiście bowiem, jak stwierdził lider wyprawy, ,nie jest to łatwa decyzja, żeby wyjechać na miesiąc, nie mając zagwarantowanych noclegów, nie mając pieniędzy na noclegi, nie posiadając zabezpieczenia w postaci samochodu technicznego i bagażowego, wiedząc jednocześnie, że trzeba będzie przejechać $4000 \mathrm{~km}$ w cywilizacji i na odludziach, w upale i chłodzie, w deszczu i zimnie" ${ }^{43}$. Podejmując jednak taki wysiłek i pewne ryzyko wiary, uczestnicy chcieli właśnie swoją ,wiarę pogłębiać, wyrażać i nią się dzielić" ${ }^{44}$.

\section{Podsumowanie}

Papieskie wezwanie, by wychodzić z Ewangelią na peryferie, otwiera niezwykle szerokie perspektywy pastoralne. Domaga się bowiem kreatywnej postawy zarówno w duszpasterstwie parafialnym, jak i w próbach podejmowania działań nadzwyczajnych. Wydaje się, że świadectwa uczestników wypraw organizowanych od jedenastu lat przez Niniwa Team wychodzą naprzeciw papieskiemu postulatowi, ponieważ ukazują, że kolejny obszar aktywności człowieka może zostać zewangelizowany i może stawać się skutecznym narzędziem ewangelizacji. Zarówno ludzkie peryferie egzystencjalne, jak i terytorialne wołają o ucywilizowanie ich drogą, którą jest Jezus. Rowerzyści często odnosili się do metaforycznego spojrzenia na drogę, którą przemierzali. I choć sam lider wypraw

${ }^{42}$ T. Maniura, Wstęp, w: Wyprawa 2013..., dz. cyt., s. 9.

43 T. Maniura, Wstęp, w: K. Zieliński, T. Maniura, Misja BXVI. Nordkapp, dz. cyt., s. 8.

${ }^{44}$ T. Maniura, Wstęp, w: K. Zieliński, T. Maniura, Misja BXVI. Nordkapp, dz. s. 9. 
na pytanie, dlaczego organizuje właśnie wyprawy rowerowe, nie znajduje odpowiedzi ${ }^{45}$, dając jednocześnie argument adwersarzom, którzy nie kryją zdziwienia dość osobliwą formą duszpasterzowania, to jednak trudno nie zauważyć dobrych owoców przemiany młodych ludzi, którzy okazują wielką determinację, by pokonać trudną drogę do oddalonego o tysiące kilometrów celu, drogę w głąb siebie, drogę do drugiego człowieka i tę najważniejszą - drogę do Boga. Wysiłek rowerzystów może być cenną inspiracją dla duszpasterzy, którzy wahają się, jaki nadać kierunek i styl swojej działalności pastoralnej - lekki i przyjemny, czy też wymagający i odkrywczy. Uczestnicy wypraw ukazują niewątpliwe zalety duszpasterstwa, w którym wiele się od nich wymaga.

Ciekawym obszarem dalszych badań aktywności „Niniwa Team byłoby zweryfikowanie po kilku latach rzeczywistej mocy oddziaływania wypraw na dalsze losy rowerzystów - na ile zmienił lub umocnił się ich system wartości i czy pozostał trwały. Na podstawie relacji z wypraw i świadectw złożonych przez ich uczestników można stwierdzić, że ewangelizacja - zarówno w wymiarze ad intra, jak i ad extra - prowadzona $\mathrm{w}$ ramach długodystansowych wypraw rowerowych jest dobrym narzędziem wchodzenia w głębszą relację z Bogiem, poprzez doświadczanie Jego opatrzności i odpowiedź wiary na wypowiadane przez Niego słowo.

45 T. Maniura, Wstęp, w: Tour de Mazenod..., dz. cyt., s. 11, stwierdził: „Warto jeszcze [...] zadać pytanie, które często słyszę: dlaczego wyprawy rowerowe? Krótko odpowiadam: nie wiem. Tak wyszło. Patrząc z perspektywy czasu na życie, to niewiele da się zaplanować czy przewidzieć. Podobnie jest z tymi wyprawami rowerowymi. Nie znam nazwisk znanych kolarzy, nie jestem pasjonatem sprzętu rowerowego. Od najmłodszych lat nie byłem fanem tego czy nawet jakiegokolwiek innego sportu. Warto mieć szeroko otwarte oczy, warto mieć pragnienia, trochę odwagi, poczucia humoru, optymizmu, umieć pośmiać się z siebie, cieszyć się, jak coś nie wyjdzie. Z takiej postawy mogą rodzić się różne rzeczy, wydarzenia, a nawet dzieła. Bóg jest najlepszym reżyserem". 


\section{Summary}

\section{Głoszenie Ewangelii podczas wypraw rowerowych na przykładzie działalności Niniwa Team}

Postulat głoszenia Ewangelii na peryferiach domaga się twórczego podejścia ewangelizatorów i jeszcze większego otwarcia na inspirację Ducha Świętego. Jedną z możliwych odpowiedzi, otwierających nowe horyzonty ewangelizacyjne, proponują organizatorzy wypraw rowerowych Niniwa Team. Analiza wypowiedzi uczestników wypraw pozwoliła dokonać eksploracji oddziaływań ewangelizacyjnych zarówno w ich wymiarze ad intra, jak i ad extra i wyprowadzić pozytywny wniosek o rzeczywistej wartości ewangelizacyjnej tak niecodziennych aktywności pastoralnych.

Słowa kluczowe: ewangelizacja, głoszenie Ewangelii, wyprawy rowerowe,

Niniwa Team

Proclaiming the Gospel during Bicycle's Tours

by the Example of the Niniwa Team

The postulate of proclaiming the Gospel on the periphery calls for the creative approach of evangelizers and a greater opening to the inspiration of the Holy Spirit. One of the possible answers, which opens new horizons for evangelization, is proposed by the organizers of the Niniwa Team. The analysis of the participants' statements allowed us to explore the evangelization's interactions in their internal and external dimensions, and to draw a positive conclusion about the real value of evangelizing such extraordinary pastoral activities.

Keywords: evangelization, preaching the Gospel, cycling tours, Niniwa Team

\section{Bibliografia}

3,6 s - Ekspedycja Jerozolima, red. K. Zieliński, Lubliniec-Kokotek 2011.

Benedykt XVI, Encyklika Deus caritas est.

Benedykt XVI, List apostolski Porta fidei.

Brajlich S., Wspomnienia uczestników, w: K. Zieliński, T. Maniura, Misja BXVI. Nordkapp, Lubliniec-Kokotek 2012, s. 295-296.

Fleiszner B., Wspomnienia uczestników, w: K. Zieliński, T. Maniura, Misja BXVI. Nordkapp, Lubliniec-Kokotek 2012, s. 299-300.

Franciszek, Adhortacja apostolska Evangelii gaudium.

Franciszek, Encyklika Lumen fidei. 
http://niniwa.org/niniwa-team.

Jan Paweł II, Encyklika Redemptoris missio.

Jaruszowiec R., Wspomnienia uczestników, w: Misja JuT. Ostatnie okrążenie, albo i nie..., red. K. Zieliński, T. Maniura, Lubliniec-Kokotek 2016, s. 376.

Kępiński A., Wspomnienia uczestników, w: Misja JuT. Ostatnie okrążenie, albo inie..., red. K. Zieliński, T. Maniura, Lubliniec-Kokotek 2016, s. 377-378.

Kotas J., Wspomnienia uczestników, w: K. Zieliński, T. Maniura, Misja BXVI. Nordkapp, Lubliniec-Kokotek 2012, s. 300-301.

Machelska U., Projekt organizacji wyprawy rowerowej z Polski na Syberię [mps, praca magisterska], Politechnika Śląska [brw].

Maniura T., Wspomnienia uczestników, w: K. Zieliński, T. Maniura, Misja BXVI. Nordkapp, Lubliniec-Kokotek 2012, s. 294-295.

Maniura T., Wstęp, w: K. Zieliński, T. Maniura, Misja BXVI. Nordkapp, LubliniecKokotek 2012, s. 8-11.

Maniura T., Wstęp, w: Misja JuT. Ostatnie okrążenie, albo i nie..., red. K. Zieliński, T. Maniura, Lubliniec-Kokotek 2016, s. 7-13.

Maniura T., Wstęp, w: Tour de Mazenod. Rowerami do Maroka, red. K. Zieliński, Lubliniec-Kokotek 2011, s. 9-13.

Maniura T., Wstęp, w: Wyprawa 2013. Polska-Syberia, red. K. Zieliński, T. Maniura, Lubliniec-Kokotek 2016, s. 7-13.

Maniura T., Wstęp, w: Wyprawa 2015. Radość życia, red. K. Zieliński, T. Maniura, Lubliniec-Kokotek 2015, s. 6-11.

Misja JuT. Ostatnie okrążenie, albo i nie..., red. K. Zieliński, T. Maniura, LubliniecKokotek 2016.

Paweł VI, Adhortacja apostolska Evangelii nuntiandi.

Polska-Syberia. Dokąd?, http://niniwa.org/niniwa-team/dokad-2-2/ (20.09.2017).

Ratzinger J., Wprowadzenie w chrześcijaństwo, tłum. Z. Włodkowa, Kraków 2006.

Szendzielorz K., Wspomnienia uczestników, w: Tour de Mazenod. Rowerami do Maroka, red. K. Zieliński, Lubliniec-Kokotek 2011, s. 294-295.

Wyprawa w nieznane, red. P. Zakowicz, T. Maniura, Lubliniec 2014.

Zieliński K., Maniura T., Misja BXVI. Nordkapp, Lubliniec-Kokotek 2012.

Zieliński S., Wspomnienia uczestników, w: Misja JuT. Ostatnie okrażenie, albo i nie..., red. K. Zieliński, T. Maniura, Lubliniec-Kokotek 2016, s. 395-396.

Pawlina K., Jak młodym mówić o Bogu dziś... Odpowiedzi młodzieży na Kwestionariusz rzymski, Warszawa 1995.

Pock J., Zwischen Videoclips und SMS:Wort-Verkündigung unter den Bedingungenvder Medienkultur, „Pastoraltheologische Informationen” 27 (2007), s. 68-79.

Polityka młodzieżowa, red. G.Zielińska, Warszawa 2009 (Studia Biura Analiz Sejmowych Kancelarii Sejmu, 2(18)).

Sławiński H., Autorytet kaznodziei wsparciem autorytetu rodziców, w: Rodzina szkoła wartości, red. A. Pryba, Poznań 2011, s. 133-142 (Colloquia Disputationes, 18).

Sławiński H., Kontekstualne uwarunkowanie głoszenia katechez do młodzieży, „Pro Musica Sacra" 13 (2005), s. 53-69. 
Sławiński H., Segmentacja rynku i przepowiadanie do wielopokoleniowego audytorium, w: „Musimy siać”. Księga pamiątkowa ku czci Gerarda Siwka CssR (1938-2015), red. M. Pawliszyn, Kraków 2016, s. 350-351.

Zaręba S., Religijność młodzieży - podstawowe parametry, w: Religia - Kościót - społeczeństwo, red. W. Zdaniewicz, S. Zaręba, Warszawa 2006, s. 110-139. 